\title{
IATROGENIC URINARY TRACT INJURY IN OBSTETRIC AND GYNECOLOGICAL PROCEDURES: FIVE-YEAR- EXPERIENCE FROM TWO UNIVERSITY HOSPITALS
}

\author{
By
}

\author{
Abd Allah M. El-Mogy ${ }^{1}$, Ahmed G. Abd El-Raouf ${ }^{1}$, Ali G. Ayad ${ }^{1}$, Hany \\ M. Abd El-Aal ${ }^{2}$ \\ ${ }^{1}$ Department of Urology, ${ }^{2}$ Department of Obstetrics and Gynecology, Faculty of Medicine, \\ Al-Azhar University (Cairo) \\ Corresponding author: Abd Allah M. El-Mogy, \\ Mobile: 01008987113, E-mail: zakizaki10@yahoo.com
}

\begin{abstract}
Background: Owing to improvements in gynecological and obstetric techniques that help to prevent urinary tract injury and immediate recognition and repair of any injury occur, long-term complications are less frequent nowadays.

Aim of the Work: To evaluate the role and importance of the presence of a urogynecology team in management of Obstetrics and gynecology cases with high risk of urological injuries for preoperative assessment, intra operative management and post operatively for follow up of cases repaired and cases need late management like cases presented with urinary tract fistulae.

Patients and Methods: This retrospective study included all patients with genitourinary injuries following obstetric and gynecologic procedures that were treated at the Department of Urology and department of obstetrics and gynecology, Al-Hussein and Sayed Galal University Hospitals during the past 5 years. All cases with urological injuries were managed by urogynecological team of urology department of Al-Azhar Cairo University.

Results: In our study we detected 97 cases. We found 35 patients $(36.1 \%)$ were complicated in gynecological procedures while 62 patients (63.9\%) were complicated in obstetric procedures, As regard our study three types of injuries were detected ureteric injuries (8.2\%), bladder injuries (27.8\%) and fistula formation $(63.9 \%)$.

Conclusion: Complicated gynecological and obstetric procedures with high risk of urological injuries should be managed in collaboration between obstetric ,gynecological and urogynecological teams for: preoperative assessment or intervention like; endoscopic stent fixation in cases with risk of injury, early detection of any urological injuries in all gynecological and obstetric procedures, early intervention and management of all types of urological injuries and follow up all managed patients and assessment and preparation of all cases need late repair.
\end{abstract}

Key words: Iatrogenic urinary tract injury, obstetrics and gynecological procedures. 


\section{INTRODUCTION}

The female genital and urinary tracts are anatomically closely related; therefore, the potential for injury to one must always be considered when operating on the other (Lee et al., 2012).

The risk of damage increases when the normal anatomy is altered by primary pathologic factors or when it is insufficiently identified during intraoperative complications, such as severe bleeding or pelvic adhesions (Ozdemir et al., 2011). Urinary tract injuries due to obstetric and gynecologic surgery are normally divided into two categories: acute complications such as bladder injury or injury of the ureter that can be identified immediately during the operation and chronic complications such as vesicovaginal fistula, ureterovaginal fistula, vesicouterine fistula and ureter stricture, which can occur later (Lee et al., 2012).

To avoid injury to the urinary tract, the gynecologist must have an accurate understanding of pelvic anatomy; use a meticulous and methodical surgical technique. In the case of ureter injury, early detection and treatment can prevent the deterioration of renal function and bring about a satisfactory prognosis (Ozdemir et al., 2011).

The aim of our work was to report urological complications resulting from gynecological and obstetric procedures in the period from January 2015 till December 2019 in gynecological and obstetric department of Al-Azhar university (Al-Hussein and Sayed Galal hospitals) with analysis of such injuries for types, possible predisposing factor, management and follow up of all reported cases at the same period in order to minimize this occurrence in the future.

\section{PATIENTS AND METHODS}

This study was Retrospective study included all patients with genitourinary injuries following obstetric and gynecologic procedures who were treated at the Department of Urology in collaboration with obstetrics and gynecology department, Al-Hussein and Sayed Galal University Hospitals during the past 5 years.

In each patient we reported the following: Full history taking including the predisposing factors for urological injuries (previous surgery, irradiation, sever intraoperative bleeding ...ect), Physical examination, Type of gynecological and obstetric procedure that was done and leaded to urological injury, Type and location of injury, degree of Gynecological surgeon experience, Type of repair performed for each patient either surgical or endoscopic and outcome, Follow up of all patients and detection of any complication after repair: Patients had an abdominopelvic ultrasound and IVP, Full scanning was done for patients with suspected impaired renal function (blood chemistry, CTurography, ultrasonography ...etc).

Patients who had a bladder injury were followed up using ascending cystourethrogram three weeks after repair before removal of the catheter.

\section{Statistical Analsysis:}

Recorded data were analyzed using the statistical package for social sciences, version 20.0 (SPSS Inc., Chicago, Illinois, 
USA). Quantitative data were expressed as mean \pm standard deviation (SD). Qualitative data were expressed as frequency and percentage. The following tests were done: Independent-samples ttest of significance was used when comparing between two means. Chi- square $\left(\mathrm{x}^{2}\right)$ test of significance was used in order to compare proportions between qualitative parameters. The confidence interval was set to $95 \%$ and the margin of error accepted was set to 5\%.p value $\leq$ 0.05 considered significant.

\section{RESULTS}

This study included 97 female patients who had urological injury during either gynecological or obstetric procedure.
The mean age of the study subjects was $40.94 \pm 8.44$ years, and the mean BMI was31.58 \pm 5.23 (Table 1).

Table (1): Age and BMI of study subjects

BMI: body mass index, SD: standard deviation

\begin{tabular}{|c|c|c|c|c|}
\hline Parameters & Mean & SD & Minimum & Maximum \\
\hline Age (years) & 40.94 & \pm 8.44 & 20 & 57 \\
\hline BMI $\left(\mathrm{kg} / \mathrm{m}^{2}\right)$ & 31.58 & \pm 5.23 & 22 & 44 \\
\hline
\end{tabular}

The distribution of co-morbidities among patients as follow; DM (18.6\%),

HTN (12.4\%) and cardiac (9.3\%) (Table 2).

Table (2): Medical co-morbidities of study subjects

\begin{tabular}{|c|c|c|}
\hline Co-morbidities & Count & \% \\
\hline DM & 18 & 18.6 \\
\hline HTN & 12 & 12.4 \\
\hline Cardiac & 9 & 9.3 \\
\hline
\end{tabular}

DM: Diabetes mellitus, HTN: hypertension,

Patient may present by more than one co-morbidity

The distributions of cases with injuries were 62 with cesarean section and 35 with hysterectomy (Table 3).

Table (3): Distribution of cases according to their gynecological and obstetric procedures

\begin{tabular}{|c|c|c|}
\hline procedures & Count & $\%$ \\
\hline Cs & 62 & 63.9 \\
\hline Hysterectomy & 35 & 36.1 \\
\hline Total & 97 & 100 \\
\hline
\end{tabular}

Ureter Injured in $8.2 \%$ of cases, bladder Injured in $27.8 \%$ of cases and
Fistula injuries were $63.9 \%$ of cases (Table 4). 
Table (4): Distribution of cases according to type of urological injury

\begin{tabular}{|c|c|c|}
\hline & No. & \% \\
\hline Ureter Injured & 8 & $8.2 \%$ \\
\hline Bladder Injured & 27 & $27.8 \%$ \\
\hline Fistula injuries & 62 & $63.9 \%$ \\
\hline Total & 97 & $100.0 \%$ \\
\hline
\end{tabular}

There was a statistically significant risk factors for ureteric injuries are surgical procedure, low surgical experience and previous surgery. In our study, $8(8.2 \%)$ patients developed ureteric injuries. discovered intraoperative while 17 (17.5 $\%)$ presented later on by uretero vaginal fistulae. Of those patients, $3(37.5 \%)$ patients underwent ureteral stent placement, $5(62.5 \%)$ underwent ureterovesical implantation, and. All those patients did not develop any complications after surgical correction except one patient who developed ureteric stricture and replanted again (Table 5).

Table (5): Incidence of ureteric injury according to risk factors

\begin{tabular}{|c|c|c|c|c|c|c|c|}
\hline \multirow{3}{*}{\multicolumn{2}{|c|}{ Risk factors }} & \multicolumn{4}{|c|}{ Ureter Injured } & \multirow{2}{*}{\multicolumn{2}{|c|}{ Chi-square test }} \\
\hline & & \multicolumn{2}{|c|}{ Injured $(n=8)$} & \multicolumn{2}{|c|}{ Not Injured $(n=89)$} & & \\
\hline & & No. & $\%$ & No. & $\%$ & $x^{2}$ & \\
\hline \multirow{2}{*}{$\begin{array}{c}\text { Surgical } \\
\text { procedure }\end{array}$} & $\mathrm{CS}$ & 2 & $25.0 \%$ & 60 & $67.4 \%$ & \multirow{2}{*}{5.726} & \multirow{2}{*}{$0.017 *$} \\
\hline & Hysterectomy & 6 & $75.0 \%$ & 29 & $32.6 \%$ & & \\
\hline \multirow{2}{*}{$\begin{array}{c}\text { Surgical } \\
\text { experience }\end{array}$} & High & 1 & $12.5 \%$ & 39 & $43.8 \%$ & \multirow{2}{*}{4.971} & \multirow{2}{*}{$0.035^{*}$} \\
\hline & Low & 7 & $87.5 \%$ & 50 & $56.2 \%$ & & \\
\hline \multirow{3}{*}{$\begin{array}{l}\text { Abnormal } \\
\text { placenta }\end{array}$} & No & 6 & $75.0 \%$ & 33 & $37.1 \%$ & \multirow{3}{*}{4.395} & \multirow{3}{*}{0.129} \\
\hline & $\begin{array}{c}\text { Yes placenta } \\
\text { acreta }\end{array}$ & 1 & $12.5 \%$ & 30 & $33.7 \%$ & & \\
\hline & $\begin{array}{l}\text { Yes placenta } \\
\text { percreta }\end{array}$ & 1 & $12.5 \%$ & 26 & $29.2 \%$ & & \\
\hline \multirow{2}{*}{$\begin{array}{l}\text { Previous } \\
\text { surgery }\end{array}$} & No & 1 & $12.5 \%$ & 38 & $42.7 \%$ & \multirow{2}{*}{3.784} & \multirow{2}{*}{$0.045^{*}$} \\
\hline & Yes & 7 & $87.5 \%$ & 51 & $57.3 \%$ & & \\
\hline
\end{tabular}

There was a statistically significant risk factor is abnormal placenta specially placenta percreta (Table 6).

Table (6): Distribution of cases according to risk factors $(n=27)$

\begin{tabular}{|c|c|c|c|c|c|}
\hline \multirow{2}{*}{\multicolumn{2}{|c|}{ Risk factors }} & \multicolumn{2}{|c|}{ Bladder Injured $(\mathrm{n}=27)$} & \multicolumn{2}{|c|}{ Chi-square test } \\
\hline & & No. & $\%$ & $\mathrm{x} 2$ & p-value \\
\hline \multirow{2}{*}{$\begin{array}{c}\text { Surgical } \\
\text { experience }\end{array}$} & High & 21 & $77.8 \%$ & \multirow{2}{*}{4.180} & \multirow{2}{*}{0.050} \\
\hline & Low & 6 & $22.2 \%$ & & \\
\hline \multirow{3}{*}{$\begin{array}{c}\text { Abnormal } \\
\text { placenta }\end{array}$} & Normal placenta & 6 & $22.22 \%$ & \multirow{3}{*}{5.567} & \multirow{3}{*}{0.017} \\
\hline & placenta acreta & 8 & $29.62 \%$ & & \\
\hline & placenta percreta & 13 & $48.14 \%$ & & \\
\hline $\begin{array}{c}\text { Previous } \\
\text { surgery }\end{array}$ & No & 21 & $77.8 \%$ & 4.180 & 0.050 \\
\hline
\end{tabular}


The study showed the following findings: Time of diagnosis: All patients with bladder injuries were discovered intra- operative. Type of bladder injury: 7 of our patients $(25.9 \%)$ had a posterior wall and domal tear. 20 of our patients (75.1\%) had a domal tear only. Predisposing factors: 5 patients $(18.5 \%)$ had a history of previous abdominal operation and were injured during open hysterectomy. 21 patients $(81.5 \%)$ injured during obstetric procedure; 2 patients of them were known to have placenta percreta with recurrence (they were complicated by posterior wall and domal injury), 19 of them had a placenta acreta and complicated by domal tear.
All patients had bladder repair (bladder was closed in two layers using absorbable (2-0 sutures). All patients $(100 \%)$ had only urethral catheter fixation.

All patients were followed after 3 weeks by ascending cysto-urethrogram under complete aseptic condition showed: no leakage or pelvic collection, urethral catheters were removed in all cases. All patients were followed up by pelviabdominal ultrasound after one month which showed no pelvic collection and good bladder distention and emptying with no significant post voiding urine.

There were statistically significant risk factors which were low surgical experience, abnormal placenta and previous surgery (Table 7).

Table (7): Distribution of cases of genitourinary fistula according to risk factors $(\mathrm{n}=62)$

\begin{tabular}{|c|c|c|c|c|c|}
\hline \multirow{2}{*}{\multicolumn{2}{|c|}{$\begin{array}{l}\text { Gynecological and } \\
\text { obstetric procedures }\end{array}$}} & \multicolumn{2}{|c|}{ Fistula injuries $(n=62)$} & \multicolumn{2}{|c|}{ Chi-square test } \\
\hline & & No. & $\%$ & $\mathbf{x} 2$ & p-value \\
\hline \multirow{2}{*}{$\begin{array}{c}\text { Surgical } \\
\text { experience }\end{array}$} & High & 18 & $29.0 \%$ & \multirow{2}{*}{40.985} & \multirow{2}{*}{$<0.001$} \\
\hline & Low & 44 & $71.0 \%$ & & \\
\hline \multirow{3}{*}{$\begin{array}{c}\text { Abnormal } \\
\text { placenta }\end{array}$} & Normal placenta & 11 & $17.7 \%$ & \multirow{3}{*}{35.613} & \multirow{3}{*}{$<0.001$} \\
\hline & placenta acreta & 28 & $45.2 \%$ & & \\
\hline & placenta percreta & 23 & $37.1 \%$ & & \\
\hline \multirow{2}{*}{$\begin{array}{l}\text { Previous } \\
\text { surgery }\end{array}$} & No & 17 & $27.4 \%$ & \multirow{2}{*}{42.503} & \multirow{2}{*}{$<0.001$} \\
\hline & Yes & 45 & $72.6 \%$ & & \\
\hline
\end{tabular}

$\mathrm{x}^{2}$ : Chi-square test; $* *$ p-value $<0.001 \mathrm{HS}$

There were 26 cases with vesico vaginal fistula and 19 cases with uterine fistula, 17 cases with uretro vesicovaginal fistula (Table 8).

Table (8): Distribution of cases according to type of fistulous injuries

\begin{tabular}{|c|c|c|}
\hline Type of Fistula & No. & \% \\
\hline Vesico uterine fistula & 26 & $41.9 \%$ \\
\hline Uretro vaginal fistula & 17 & $27.4 \%$ \\
\hline Vesico vaginal fistula & 19 & $30.6 \%$ \\
\hline Total & 62 & $100.0 \%$ \\
\hline
\end{tabular}

(Table 9) : Time of diagnois

All patients $(100 \%)$ were detected post operatively ( Table 9).

\begin{tabular}{|c|c|c|c|c|}
\hline $\begin{array}{c}\text { Time of Recognition } \\
\text { post operativeoy }\end{array}$ & Early < 1 Week & Late $>$ 1week & count & \% \\
\hline Uretro Vaginal Fistula & no & yes & 17 & 27.4 \\
\hline Vesico Uterine Fistula & no & yes & 26 & 41.9 \\
\hline Vesico Vaginal Fistula & yes & no & 19 & 30.7 \\
\hline
\end{tabular}


In this study the predisposing factors (the cause of injury) were mentioned in Table(10). Predisposing factors

\begin{tabular}{|c|c|}
\hline Predisposing factors: & Number of patients \\
\hline $\begin{array}{l}\text { - } \quad \text { None. } \\
\text { - History of previous abdominal surgery or Previous } \\
\text { caesarean section }\end{array}$ & $\begin{array}{l}20(20.6 \%) \\
58(59.8 \%)\end{array}$ \\
\hline - $\quad$ Placenta accreta & $31(32.0 \%)$ \\
\hline Placenta percreta & $27(27.8 \%)$ \\
\hline Low Surgical experiance & $57(58.8 \%)$ \\
\hline
\end{tabular}

All patients $(100 \%)$ were managed by delayed repair. (Table 11)

Vesico-vaginal fistula VVF:

19 Patients $(30.7 \%)$ were complicated with VVF.

Patients presented post operatively by vaginal urinary leakage and repaired after six months. Through a transabdominal approach or transvaginal approach with fixation of urethral and suprapubic catheter for complete drainage of the bladder which kept for three weeks under antibiotics, antimuscarincs and antiinflammatories were prescribed. Follow up ACU was done after three weeks of repair, patients showed no vaginal leakage Uretrovaginal fistula:

$17(27.4 \%)$ patients were detected and managed by UVI (Lich- Gregoir technique, simple nippling, boari flap) with stenting. Follow up after one month by endoscopic retrograde showed closure of the fistulous tract and stents were removed. Another follow up after one month through pelvi- abdominal ultrasound showed no back pressure at the side of the fistoulus tract and IVP after 3 months.

\section{Vesico-uterine fistula:}

26 patients $(41.9 \%)$ were detected and managed by excision of the fistolous tract and separate closure of the bladder and uterus with interposition of omentum with a urinary catheter fixed for one month and good antibiotic coverage and hormonal induction of amenorrhea. Follow up after one month was done by ACU showed successful closure of the fistoulus tract and urinary catheter was removed. (Table 11).

Table (11): Mode of delayed surgical repair of cases with fistula

\begin{tabular}{|c|l|c|}
\hline Site of lesion & Type of repair & $\begin{array}{c}\text { Number of } \\
\text { cases }\end{array}$ \\
\hline & $\bullet \quad$ Primary repair with urethreal catheter only. & $27(27 \%)$ \\
Bladder & $\bullet \quad$ Excision of ligating sutures and open stent & $3(37.5 \%)$ \\
Ureter & placement. & $5(62.5 \%)$ \\
Fistulae & $-\quad$ UVI & $7(41.1 \%)$ \\
& $-\quad$ PCN fixation and late repair. & $55(88.7 \%)$ \\
\hline
\end{tabular}

\section{DISCUSSION}

The prevention of iatrogenic trauma to the ureters depends upon the visual identification of the ureters and bladder and careful intraoperative dissection in their proximity. The use of prophylactic preoperative ureteral stent insertion assists in visualization and palpation of the ureters (Speicher et al., 2014). 
The bladder is the urological organ that most often suffers iatrogenic injury (Cordon et al., 2014).

Extravasation of urine, visible laceration, clear fluid in the surgical field, appearance of the bladder catheter, and blood and/or gas in the urine bag during laparoscopy. Direct inspection is the most reliable method of assessing bladder integrity. Intravesical instillation of methylene blue may be helpful. If bladder perforation is close to the trigone, the ureteric orifices should be inspected (Cordon et al., 2014).

Preoperatively, the urologist may be counseled to insert a ureteric catheter prophylactically before the occurrence of complications (Chou et al., 2009).

European association of urology recommendations for management of bladder injuries are Cystography is the preferred diagnostic modality for noniatrogenic bladder injuries, and in suspected, iatrogenic, post- operative, bladder injuries Cystography (conventional or CT imaging) is required in the presence of visible haematuria and pelvic fracture. Cystography should be performed with filling of the bladder with at least $350 \mathrm{~mL}$ of dilute contrast. It is optional after any other type of sling procedure or transvaginal mesh procedure. In the absence of bladder neck involvement and/or associated injuries that require surgical intervention, extra peritoneal bladder ruptures caused by blunt trauma are managed conservatively. Intraperitoneal bladder ruptures by blunt trauma, and any type of bladder injury by penetrating trauma must be managed by emergency surgical exploration and repair. Conservative management is an option for small, uncomplicated, iatrogenic intraperitoneal bladder perforations (Summerton et al., 2015).

In this study 97 female patients were included who had urological injuries that occurred during either gynecological or obstetric procedures in the gynecological and obstetric department in Al-Hussein and Sayed Galal University Hospitals. During the past 5 years. Patient's age ranged from 20 to 57 years.

In this study the incidence of urological injuries was higher in obstetric procedures $63.6 \%$ compared to $36.1 \%$ in gynecological procedures. Three types of injuries were detected ureteric injuries (8.2\%), bladder injuries (27\%) and fistula formation $(63.9 \%)$.

Urological complications were defined as laceration, transection, rupture, or ligation of the genitourinary tract found during surgery or as hydronephrosis and leakage of contrast media out of the urinary tract found after surgery that required interventional or surgical treatment.

In our study the incidence for urinary bladder $(27 \%)$ and ureteric injuries $(8.2 \%)$ and fistulae had an incidence $(63.9 \%)$ this was against Lee et al. (2012), with the high incidence was for urinary bladder injury $(71.1 \%)$ and Pal et al. (2016) with the high incidence for VVF (51.3\%).

\section{CONCLUSION}

Complicated gynecological procedures and high risk pregnancy (surgical obstetric emergency) should be managed in collaboration of urogynecological team for preoperative assessment or intervention like; endoscopic stent fixation in cases with risk of injury, early detection 
of any urological injuries in all gynecological and obstetric procedures, early intervention and management of all types of urological injuries, follow up all managed patients and assessment and preparation of all cases need late repair.

\section{REFERENCES}

1. Chou MT, Wang CJ and Lien RC. (2009): Prophylactic ureteral catheterization in gynecologic surgery: a 12-year randomized trial in a community hospital. International Urogynecology Journal, 20(6):689-93.

2. Lee JS, Choe JH, Lee HS and Seo JT. (2012): Urologic complications following obstetric and gynecologic surgery. Korean Journal of Urology, 53(11), 795-799.

3. Ozdemir E, Ozturk U, Celen S, Sucak A, Gunel M, Guney $G$ and Danisman AN. (2011): Urinary complications of gynecologic surgery: iatrogenic urinary tract system injuries in obstetrics and gynecology operations.
Clinical and Experimental Obstetrics \& Gynecology, 38(3), 217-220.

4. Pal DK, Wats $V$ and Ghosh B. (2016): Urologic complications following obstetrics and gynecologicai surgery: Our experience in a tertiary care hospital. Urology Annals, 8(1):26.

5. Summerton, D. J., Kitrey, N. D., Lumen, N., Serafetinidis, E., \& Djakovic, N. (2015): EAU guidelines on iatrogenic trauma. European Urology, 62(4): 628-639.

6. Speicher, P. J., Goldsmith, Z. G., Nussbaum, D. P., Turley, R. S., Peterson, A. Cand Mantyh, C. R. (2014): Ureteral stenting in laparoscopic colorectal surgery. Journal of Surgical Research, 190(1), 98-103.

7. Cordon BH, Fracchia JA, Armenakas NA (2014): Iatrogenic nonendoscopic bladder injuries over 24 years: 127 cases at a single institution. Urology 84(1):222-6. 
إصابات المساللك البوليه الناتجه عن جر احات أمر اض النساء و التوليد: خبره خمس سنوات من مستشفيين جامعيين عبدالله محمد زكى نصر الموجى1، أحمد جمال الدين عبدالرؤوف1، على جمعه عيد

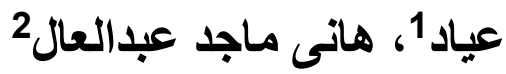

1قسم جراحة المسالك البولية، 2قسم جراحة النساء والتوليد، كلية الطب، جامعة الأزهر (القاهرة)

E-mail: zakizaki10@yahoo.com

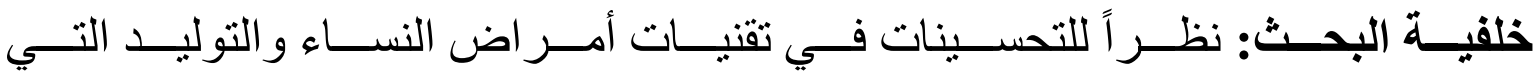

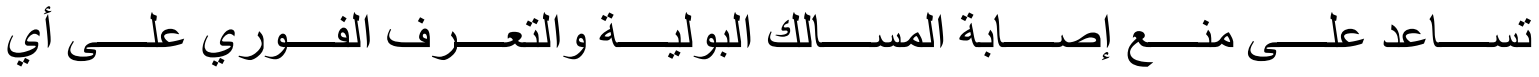

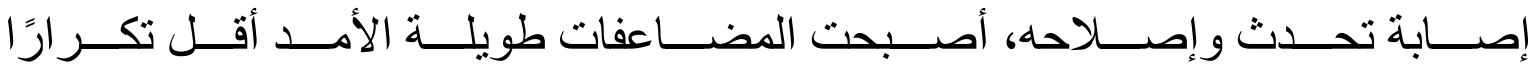

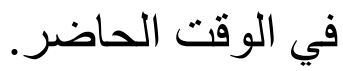

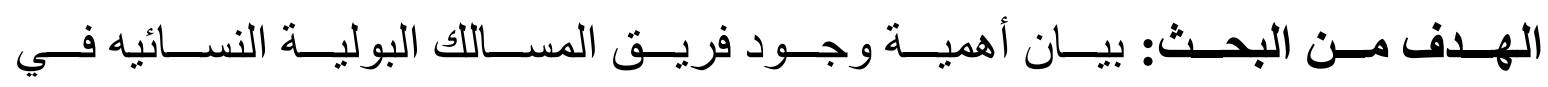

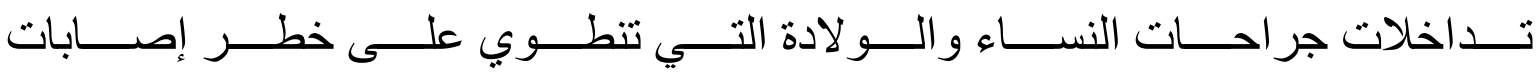

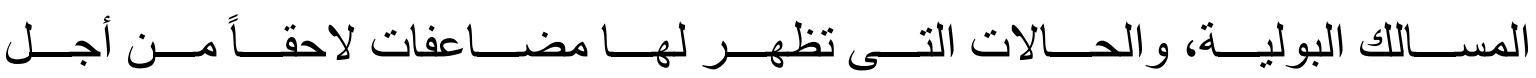

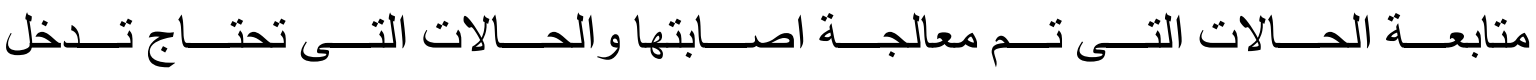

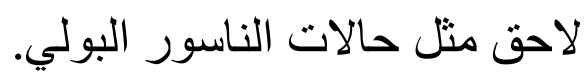

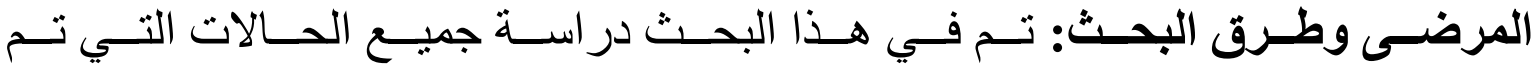

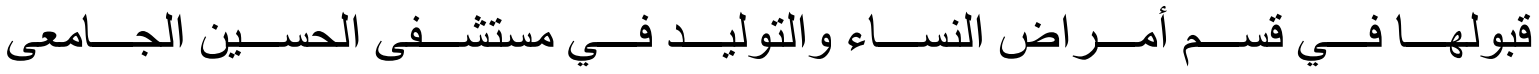

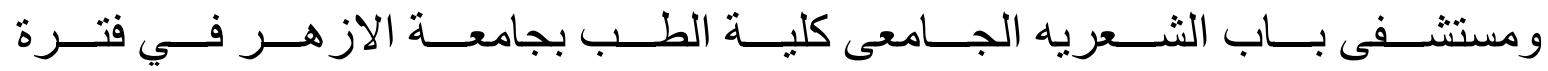

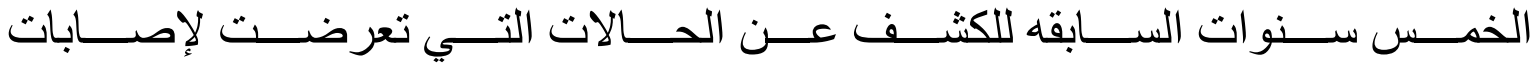

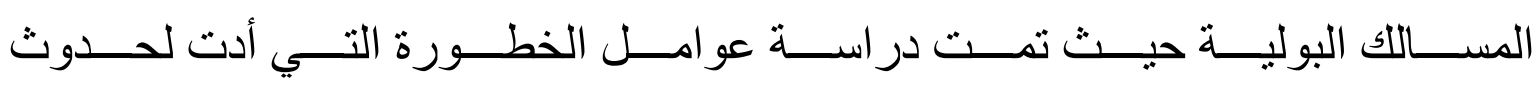

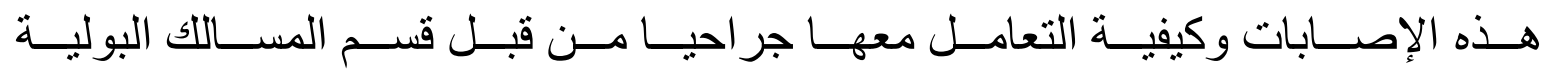
بمستشفى كلية الطب بجامعة الأزهر. 


\section{ABD ALLAH M. EL-MOGY et al.,}

النتـائج: نــتج عـن در اســـة ملفــات المرضــى وجــود 97 حالـــة أصـــابه للمســالك

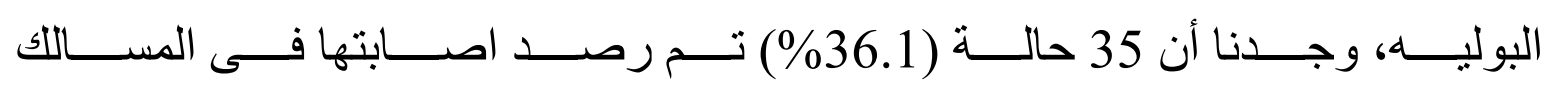

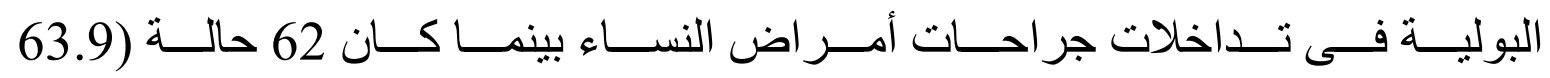

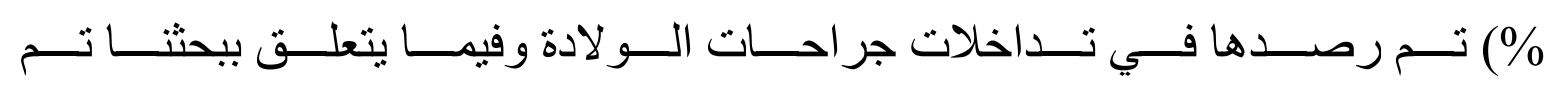

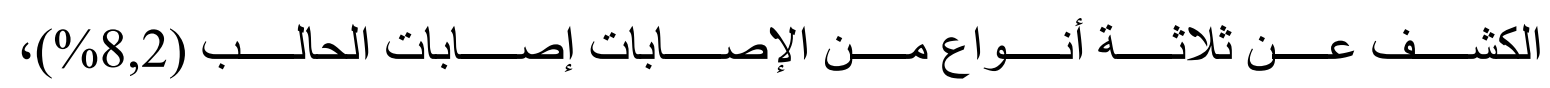
إصابات المثانة (27,8\%) وتشكيل الناسور (63,9\%).

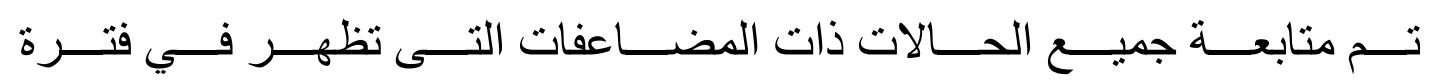

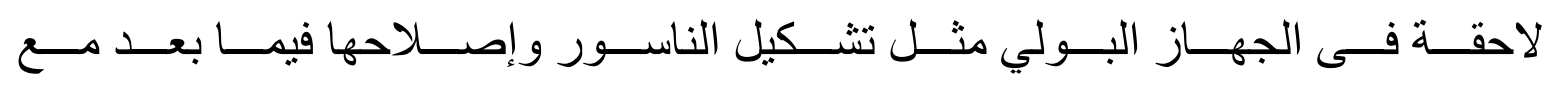
نفس الفريق.

الكلمات الدالة: اصابات المسالك البوليه أثناء جر احات النساء و التوليد. 